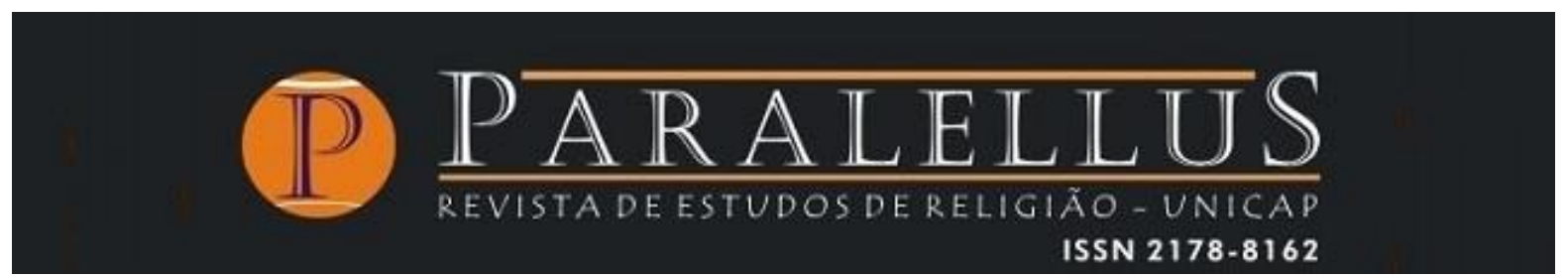

Volume 12 - Número 30

DOSSIÊ: A SABEDORIA NAS SAGRADAS ESCRITURAS

doi: 10.25247/paralellus.2021.v12n30.p545-567

\title{
ULTRAMONTANISMO X ILUSTRAÇÃO: ASSISTÊNCIA E EDUCAÇÃO COMO ESPAÇOS DE DISCUSSÃO POLÍTICA E RELIGIOSA NO BRASIL - SÉCULO XIX/XX
}

\author{
ULTRAMONTANISM X ILLUSTRATION: ASSISTANCE AND EDUCATION AS \\ ENVIRONMENT FOR POLITICAL AND RELIGIOUS DISCUSSION IN BRAZIL \\ $-19^{\mathrm{TH}} / 20^{\mathrm{TH}}$ CENTURIES
}

Prof. Dr. Jefferson de Almeida Pinto*

\section{ResUmo}

Este artigo trata das discussões entre a Igreja romana e os campos político e intelectual no Brasil sobre o tema da assistência e educação. Tomamos por referência o processo de reforma católica ultramontana, iniciado no século XIX e estendido até a formação da romanização no início do século XX. Nesse contexto, a Igreja contaria com a atuação de ordens religiosas, como foi o caso da Congregação da Missão que assumiu importantes funções no governo imperial, dentre as quais a assistência social e da educação. Tendo em vista o processo de laicização encampado pela ala política, buscou-se afastar a Igreja destas instituições, o que pode ser verificado nas discussões propostas no final do Segundo Reinado e nos projetos que se avistaram no início da República. No início do século XX, a lgreja reagiu a esse processo reaproximando-se dos intelectuais e do campo político, que, então, promoveria ações que lhe garantiria a influência nos setores em disputa

\footnotetext{
* Possui graduação em História pela Universidade Federal de Juiz de Fora (2001), mestrado (2004) e doutorado (2011) em História pela Universidade Federal Fluminense e Jornalismo (2020) pelo Centro Universitário Internacional, Curitiba-PR. Atualmente é professor titular do Instituto Federal do Sudeste de Minas Gerais - Campus Juiz de Fora, onde é Diretor de Pesquisa, Inovação e Pós-Graduação.
}

Paralellus, Recife, v. 12, n. 30, mai./ago. 2021, p. 545-567 
Palavras-chave: Lazaristas; Questão religiosa; Ultramontanismo; Modernização imperial; Ideias políticas

\section{ABSTRACT:}

This paper focuses on the assistance and education topics discussed between Roman Church and Brazil's political and intellectual groups. The basis of this research is the ultramontane Catholic reformation process, which started in the $19^{\text {th }}$ century and extended until the romanization establishment in the early 20th century. In this context, the Catholic Church had the support of religious orders such as the Congregation of the Mission. This group took on notable duties in the imperial government, including social and educational assistance. Considering the laicization process adopted by some political agendas, there was a movement to keep the Church away from government institutions, verified in the discussions proposed at the end of the Second Empire and the projects proposed during the early period of the Republic. At the beginning of the $20^{\text {th }}$ century, the Church reacted to this process by reconnecting itself to intellectuals and the political field. This last one would then act to guarantee its influence on the sectors in dispute.

Keywords: Lazaristes; Religion; Ultramontanism; Imperial modernization; Political Ideas. 


\section{INTRODUÇÃO}

Em meados da década de 1930, em uma de suas inúmeras aparições nas páginas da imprensa, Alceu Amoroso Lima (1893-1983) chamava a atenção para os dilemas enfrentados pela Igreja do Brasil do século XIX. Dizia ele que, naquele tempo em que o racionalismo e o bacharelismo dominavam a política, os intelectuais e políticos buscaram afastar o povo da religião, chegando-se ao cúmulo do aprisionamento de membros do clero, referindo-se à célebre "questão dos bispos" (1873-1875) (PINTO, 2016b). Prosseguindo em seus argumentos, Alceu Lima entendia que a situação já se encontrava revertida ao tempo em que escrevia, tendo em vista que ele e outros intelectuais católicos contemporâneos representavam o Brasil do século XX - o qual reabilitaria o clero e que estava levando novamente os homens para a Igreja e seus altares (CARNEIRO, 1938, p. 2).

Essa reação católica foi fruto de uma movimentação pastoral iniciada pelos idos da década de 1910 e que teve à sua frente uma figura muito importante para a afirmação do clero no interior do campo político e intelectual brasileiro: o arcebispo de Olinda, Recife, Dom Sebastião Leme da Silveira Cintra (1882-1942), que seria, posteriormente, arcebispo do Rio de Janeiro. Para esse prelado, a Igreja passava por muitos percalços, justificados pela ausência de uma intelectualidade que permitisse discutir e defender seus posicionamentos quanto ao perfil de sociedade que se queria e que deveria ser implantado, sobretudo após o advento republicano de 1889 (MAINWARING, 2004, p. 41).

Para além da questão intelectual, Dom Sebastião também encampou, à época da instauração do primeiro governo Vargas (1930-1945), estratégias para assegurar à Igreja o seu lugar na sociedade e na política brasileira, a exemplo da chamada Liga Eleitoral Católica (LEC). Por meio desta, a Igreja buscava se aproximar dos políticos defensores do catolicismo e de seus interesses, independente de que grupos ou partidos políticos esses estadistas estivessem atrelados, excluindo-se, evidentemente, o Partido Comunista do Brasil (RELIGIÃO..., 1932, p. 1).

Nosso objetivo neste artigo é discutir as razões das tensões entre a Igreja e o campo político e intelectual apontadas por Alceu Lima e Dom Sebastião Leme. Perguntamonos, a princípio, que razões estavam por trás dessas animosidades institucionais do 
século XIX e que levaram a essa profunda necessidade de repactuação por eles apontada. Quais eram suas dimensões políticas? Quais eram os principais pontos de tensão nesse processo histórico? Para tanto, debruçar-nos-emos sobre dois importantes pontos: a) a Reforma Ultramontana encampada por Roma no século XIX, pensando-a para além da questão doutrinária e, portanto, atentando para seus desdobramentos políticos; b) o avanço da ilustração sobre o campo político e intelectual no Brasil do século XIX e sua defesa do regalismo-galicanismo.

\section{O REGALISMO E O ULTRAMONTANISMO NO BRASIL IMPÉRIO}

De acordo com a Constituição de 1824, embora fosse permitido o livre culto, a religião oficial do Estado imperial era a Católica Apostólica Romana. A relação desta com o poder estava regulada pela prática do padroado e pelo beneplácito régio. Pelo primeiro, era possível garantir o sustento material de paróquias, dioceses e seus clérigos, sendo que estes faziam parte do corpo de funcionários públicos do Império. O segundo dava ao Imperador o direito de intervir nos negócios administrativos da Igreja, nomeando e removendo bispos e padres, aceitando ou não a entrada de ordens religiosas no país e ainda aprovando ou vetando as decisões papais editadas em Roma (SANTIROCCHI, 2015, p. 58).

Essa relação de submissão da Igreja ao Estado não era propriamente uma novidade. Desde os tempos coloniais, a monarquia portuguesa - assim como os reis da Espanha e da França - já fazia jus a esses direitos então concedidos por Roma para que a cristandade pudesse estender seus braços pelas vastas possessões coloniais dessas Coroas. À época em que o Marquês de Pombal (1750-1777) esteve à frente da administração e da política portuguesa, essa submissão da Igreja ao Estado acabou sendo reforçada, tendo em vista a postura regalista-galicanista por ele assumida, acrescida das tensões oriundas da ilustração setecentista (BEAL, 1976, p. 324).

Fazendo jus a essa prerrogativa política, durante seu reinado, em 1820, Dom João (1816-1826) direcionou dois padres da Congregação da Missão para que assumissem a direção da Capela do Hospício de Nossa Senhora Mãe dos Homens - mais tarde, Seminário e Colégio do Caraça - então localizada na província de Minas Gerais, e que the fora deixada em testamento como herança pelo seu fundador, o irmão 
Lourenço. Recém-chegados ao Brasil em 1819, os padres portugueses Leandro Rebelo Peixoto e Castro (1781-1858) e Antônio Ferreira Viçoso (1787-1875) assumiram essa empreitada, dando início a uma proximidade muito forte com a política que se assentou no Brasil do século XIX.

Fundada em Paris em 1625, por São Vicente de Paulo (1581-1660), para fomentar as missões, a Congregação atuava com recorrência junto a uma população pobre e em estado de abandono espiritual e material por parte da Igreja e de suas Ordens Mendicantes. Devido ao seu fundador, pode ser chamada também de Congregação dos Padres Vicentinos ou, ainda, Congregação dos lazaristas, tendo em vista que seus componentes habitavam inicialmente um antigo leprosário francês consagrado a São Lázaro. A Confraria das Damas da Caridade, fundada em 1617, e a Congregação das Irmãs da Caridade, ou Irmãs Vicentinas, fundada em 1633 pela dama da caridade Luísa de Marillac (1591-1660) com o auxílio de Vicente de Paulo, e a Sociedade São Vicente de Paulo, fundada em 1833 pelo beato Frederico Ozanan (1813-1853), vieram a constituir o que hoje conhecemos como a "família vicentina".

No transcorrer desse período, a Missão e outras congregações religiosas acabaram assumindo funções no quadro político-administrativo do Império, com destaque para as áreas assistenciais e educacionais. No caso da Missão, podemos ressaltar o papel desempenhado por Dom Viçoso - já na função de bispo marianense - e pelas Irmãs da Caridade, não somente frente aos pobres e abandonados de suas circunscrições diocesanas, mas também no alcance que a "família vicentina" teve em setores como o hospitalar e o educacional, como foi o caso do próprio Seminário e Colégio do Caraça, pelo qual passaram gerações de homens que, mais tarde, estiveram inseridos no campo intelectual e político do Império (PINTO, 2016a).

Já no Rio de Janeiro, as Irmãs Vicentinas, oriundas da França, e que por lá chegaram por volta de 1848, iniciaram suas atividades assumindo o controle administrativo da Misericórdia da Corte, assim como o fizeram em diversas outras Misericórdias pelo Brasil. Nesse processo de expansão, acabaram cuidando também da "roda dos expostos" e dos asilos para crianças abandonadas, que, no caso da Corte, ficou conhecido como "asilo francês". Ampliando suas atividades na cidade, as Irmãs fundaram também o Colégio da Imaculada Conceição, na praia de Botafogo, que 
buscava, através de suas mensalidades, ajudar na manutenção das obras assistenciais da Congregação (AZZI, 1992, p. 67-69).

Na Bahia, fundaram o Colégio Nossa Senhora dos Anjos para as filhas das famílias católicas baianas e, anos depois, cuidaram de fundar o Colégio da Providência para as crianças desamparadas de Salvador, mantidas com os recursos que eram destinados pela Confraria das Senhoras da Caridade, associação que se dedicava a prover o socorro aos pobres e órfãos desvalidos. Em 1862, fundaram também o Asilo de Nossa Senhora da Misericórdia, anexo à Misericórdia. Em Pernambuco, trabalharam no Hospital da Caridade, depois nomeado Hospital Dom Pedro II. Nessa época, dois acordos foram assinados, para a vinda das religiosas francesas para Recife, que contaram com a participação direta do ministério imperial nessa negociação em 1858. No Ceará, em 1865, na diocese nova administrada por um discípulo de Dom Viçoso, as religiosas também atuaram na fundação de colégios e asilos, com o intuito de ajudar na formação da sociedade cearense (AZZI, 1992, p. 7073).

Nesse panorama, a Igreja vivenciava a chamada Reforma Ultramontana. Segundo Serbin (2008, p. 78-79), trata-se de um processo de disciplinamento da Igreja brasileira, devido ao seu distanciamento - não somente geográfico, mas sobretudo doutrinário - em relação à Roma, seja por um predomínio da cultura popular nas práticas religiosas, seja por uma cultura política regalista em que seus interesses estariam submetidos aos do Estado imperial. O conceito de Reforma Ultramontana tem sido muito difundido entre estudiosos da História da Igreja no Brasil desde a década de 1970 e, mais recentemente, tem sido repensado em estudos recentes que o entendem como uma reação ao avanço do regalismo-galicanismo sobre os negócios eclesiásticos, sobretudo após a revolução francesa (OLIVEIRA, 2015, p. 13). De tal sorte que a Igreja reagiria por meio da edição da encíclica Quanta Cura (1864) e seu Syllabus, nos quais se elencavam os (assim entendidos) erros daquele tempo: panteísmo, naturalismo e racionalismo absoluto; racionalismo moderado; indiferentismo; latitudinarismo; socialismo, comunismo, sociedades secretas, sociedades bíblicas e sociedades clérico-liberais; erros sobre a Igreja e os seus direitos; erros de sociedade civil, tanto considerada em si, como nas suas relações 
com a Igreja; erros acerca da moral natural e a moral cristã; erros acerca do matrimônio cristão; erros acerca do Principado Civil do Pontífice Romano.

Atentemo-nos aqui à relação que se fazia entre a Congregação da Missão e o Ultramontanismo no século XIX, bem como de bispos que de certa forma tiveram relações de formação com os seminários governados pelos irmãos de São Vicente, como eram os casos do já citado Dom Antônio Ferreira Viçoso, Dom Luís Antônio dos Santos (1821-1870), no Ceará, e Dom Pedro Maria de Lacerda (1830-1890), que governou a Sé do Rio de Janeiro de 1868 a 1890 e era discípulo do Caraça.

Sobre esse aspecto, Sérgio Miceli (1988) destaca que, para o clero regular, o cargo episcopal não era tão pleiteado quanto para o clero secular. Segundo ele, a nomeação de um membro do clero regular para tais cargos se devia principalmente aos serviços que sua ordem poderia ter prestado à Santa Sé. Nessas circunstâncias, o sociólogo ressalta o número elevado de bispos da Congregação da Missão atuando no Brasil neste contexto. Além disso, Miceli (1988, p. 82) aponta também que duas novas ordens foram fundadas e passaram a auxiliar Roma na empreitada ultramontana: os maristas e os salesianos.

Como registrou o ainda padre Silvério Gomes Pimenta (1840-1922), os seminários brasileiros no Império estavam em sua maior parte sob a direção dos lazaristas e não deixavam nada a desejar se comparados aos estabelecimentos franceses, muitos deles regidos pelos padres da mesma Congregação (PIMENTA apud HAUCK et al., 1992). Isso se refletia na Igreja brasileira no sentido de que esta tomava uma consciência "romana", posicionando-se ao lado da ortodoxia teológica, do ultramontanismo e, portanto, ao lado da Cúria Romana (HAUCK et al., 1992, p. 198).

\section{A POLÍTICA E A IGREJA ULTRAMONTANA}

Por sua vez, no transcorrer da segunda metade do século XIX, esse monopólio católico e da "família vicentina" sobre determinados setores da administração imperial começou a gerar um desgaste com alguns segmentos que buscavam implantar determinadas mudanças visando à modernização não somente material, mas também institucional do País, no que poderíamos aqui chamar de uma busca pela laicização da sociedade brasileira. Procurou-se reduzir consideravelmente a influência da Igreja 
nos negócios de Estado, convertida em uma campanha anticlericalista, muitas vezes denominada de antijesuítica (VIEIRA, [2006?]. p. 27-59). Entende-se também que uma série de elementos políticos-ideológicos (e teológicos) se conflitavam com a instituição romana. Além do regalismo-galicanismo e do jansenismo, podemos elencar também o liberalismo, a maçonaria, o protestantismo e o positivismo (PINTO, 2016a, p. 168).

Para líderes como Saldanha Marinho, essas mudanças foram salutares e positivas, tendo em vista as necessidades de inserção do País, por exemplo, em um mercado de trabalho livre, onde a mão de obra imigrante, mas nem sempre católica, seria necessária. Neste caso, era preciso começar um processo básico de laicização, como aponta Roberto Romano (1979), capaz de possibilitar ao país romper com algumas amarras que lhe eram então impostas pela Igreja. Neste sentido, uma ampla campanha contra esse poderio clerical se assentou, sobretudo na década de 1870 em diante, culminando com o movimento republicano alguns anos mais tarde (ROMANO, 1979, p. 96-97).

Exemplos desse anticlericalismo no Império podem ser encontrados nas Memórias, de Cristiano Ottoni (1811-1896), datadas de 1875, nas Reminiscências na Imprensa e na Diplomacia (1870-1910), de Francisco Cunha (1835-1913), no Igreja e o Estado, de Saldanha Marinho, ou ainda na trajetória intelectual inicial de Ruy Barbosa (18491923), tradutor da obra O Papa e o Concílio, de autoria do teólogo alemão Johann Joseph Ignaz Von Döellinger (1799-1890), podendo-se ainda acrescentar nesse grupo Joaquim Nabuco (1849-1910) e Visconde do Rio Branco (1819-1880) (AZZI, 1978, p. 485-510).

Anos mais tarde, com a (tentativa de) fundação de uma República laica, em que as ideias liberais e positivistas se polarizavam no plano ideológico, impôs-se, entre outros, o fim do catolicismo como a religião oficial do Estado e a consolidação do registro civil. Além disso, limitaram-se os recursos pecuniários que a Igreja auferia como parte integrante da burocracia do Estado Imperial. Embora com diferenças substanciais no que se refere à forma como o Estado republicano iria se organizar, liberais e positivistas tinham por interesse transformar as instituições públicas brasileiras, até então muito controladas pela Igreja. Os liberais se jogaram 
"decididamente no domínio da imprensa, das escolas, da universidade, procurando estabelecer um campo laico 'superior à massa', criando uma linha política de produção das elites dirigentes" (ROMANO, 1979, p. 107).

Já a estratégia positivista, embora pudesse parecer num primeiro momento bem mais complacente com a Igreja, visava também

[...] estabelecer segura e definitivamente a soberania laica, o que traria, como resultado pela educação das massas, a mudança de mentalidade, sobretudo da opinião pública, a qual, de ignorante e católica, se dirigia cada vez mais para a maturidade científica do pensamento. Só isto tornaria desnecessária a crença católica no além. Pouparia, assim, os custos de guerras e campanhas contra o poder religioso, o que só viria a fortalecer o instituto eclesiástico junto aos dominados (ROMANO, 1979, p. 130-131).

Podemos atribuir à postura política positivista a garantia às classes subalternas, na ótica republicana, de direitos civis e sociais, entre os quais estavam a educação primária e a proteção à família (CARVALHO, 1987, p. 54). Ademais, atrelada a essa concepção, destaca-se a postura maçônica no que toca à assistência e à montagem de um sistema educacional voltado para os setores populares, inclusive com a fundação de escolas noturnas tanto para os filhos dos maçons quanto para as camadas populares. Entendia-se que essas medidas seriam uma forma de universalizar o ensino primário laico e combater os adversários do progresso, partidários da ignorância, do fanatismo e da intolerância (BARATA, 1999, p. 139).

Essa série de transformações drásticas na vida da Igreja não passou sem que os "culpados" viessem a ser apontados. Não somente os maçons, liberais e positivistas - defensores, em muitos casos, do regalismo-galicanismo - foram responsabilizados pelos prejuízos que estariam sendo impostos ao povo brasileiro - na concepção da Igreja, evidentemente - mas também aqueles que, entendia-se, eram os responsáveis por sua propagação, entre os quais estariam os protestantes. O problema em relação ao protestantismo era que entendia-se trazer consigo ainda mais liberalismo e, por conseguinte, um pretenso laicismo. Seria também uma ameaça às pretensões da Igreja no que se refere à sua intervenção na educação e na família, tendo em vista sua defesa do casamento civil e do ensino leigo, aos quais o Syllabus de Pio IX era definitivamente oponente. Aliado a isso, entende-se que havia, por parte dos setores 
liberais do Brasil, um relativo fascínio pelo mundo anglo-saxão (MENDONÇA, 2002, p. 69).

$\mathrm{Na}$ visão de Antônio Gouvêa Mendonça (2002), essa admiração não é necessariamente resultado das relações de dependência política datadas desde os tempos coloniais, mas sim de um interesse, pelo menos teórico, nos modelos progressistas originários da Inglaterra ou da América do Norte. Neste quadro, a explosão da chamada "questão dos bispos" na década de 1870 fez com que as mentes mais ativas daquele tempo acabassem tomando partido "se não contra a Igreja como expressão religiosa, pelo menos como instituição portadora do espírito antiliberal e antiprogressista" tornando, esse momento, "um conflito de mentalidades diferentes, de projetos de orientação política" (MENDONÇA, 2002, p. 70).

Podemos perceber que, após esse tempo, portanto, a década da "questão dos bispos", houve uma expansão do protestantismo por meio da educação. Atrelado à noção de liberalismo, assim como aos modelos anglo-saxões de progresso expressos no comércio ou na agricultura, este foi bem recebido pela classe dominante (e ilustrada) brasileira, interessada na ruptura com os modelos educacionais ainda fundados no sistema escolástico da Companhia de Jesus e aqui (e acolá) reproduzidos intencionalmente pelas ordens religiosas ultramontanas nas várias instituições que controlavam, como seria o caso dos lazaristas. Expõe Antônio Gouvêa Mendonça (2002, p. 73-74) que essas classes não estavam necessariamente interessadas na religião protestante, mas sim na educação - de corte liberal, é preciso que se diga - que os missionários podiam oferecer, proporcionando um grande sucesso à iniciativa da educação protestante naquelas últimas décadas do oitocentos no Brasil.

Em muitos dos confrontos entre católicos e protestantes na passagem à modernidade, é atribuída a estes, por parte de clérigos romanos, uma pretensão de se apropriar de determinadas instituições ou ainda fazer parte da estrutura burocrática do Estado, sobretudo com a República. Refletindo este momento, o padre Júlio Maria (18501916) fez um pronunciamento no qual insinuava e atacava uma possível aliança do Estado republicano com o protestantismo (A PEDIDOS, 1904, p. 2). Uma estratégia interessante, é verdade, pois, ao que parece, Júlio Maria procurava despertar a 
atenção da sociedade e dos católicos, utilizando-se de uma estratégia fundamentada na difusão do medo. No caso, o clérigo se referia aos metodistas, que, após o término da Guerra de Secessão nos Estados Unidos (1860-1865), emigraram para o Brasil e ganhavam cada vez mais espaço no Império, principalmente no campo educacional.

Em resposta ao pronunciamento, os protestantes defendiam que o melhor caminho para o Estado brasileiro era a manutenção da separação com a Igreja Católica, e que aquele, em hipótese alguma, naquela conjuntura, tinha intenção de se aliar com qualquer Igreja que fosse.

Cremos, reverendíssimo sr., que o único modo praticável para christianisar a República é tornar Christão seu povo.

Que os vossos padres em vez de estarem com as costas viradas para o povo, voltem-lhes a face, e com os Evangelhos em mão, preguem a doutrina e moral de Christo, e isso se conseguirá. Prelos imprimem em grande número a vossa Bíblia Catholica romana, (?) as disseminam por todo o paiz para que o povo as leia, e isso será alcançado. Ensinar os analphabetos, abrindo Ihes diante o grande livro de Deus, assim, tereis christianisado a República Brasileira por Ihe chistianisardes o povo.

A Egreja Evangélica fará com vosco causa commum; e por intermédio das sociedades bíblicas vos proporcionará a impressão em larga escala; e a custo mínimo de vossa Bíblia, mesmo com os seus livros (A PEDIDOS, 1904, p. 2).

Chama-nos a atenção, nesses episódios, a possibilidade de se pensar nas relações entre católicos e protestantes e sua vivência e influência na cultura política. Assim sendo, para estes, como nos mostra Lebrun (1991), a relação com Deus se fazia de forma direta e as vivências coletivas da religião não poderiam interferir nessa relação. Entre as vivências coletivas protestantes, podemos destacar o culto doméstico, a prédica, a ceia, o batismo, o noivado e o casamento, a solidariedade e a eleição. Diferentemente ainda dos católicos, a morte era tratada como um assunto privado.

Essa concepção da vivência da religião acabou por permitir uma diferenciação em relação a como a Igreja interferia na família. O pai, que também era geralmente o chefe do culto familiar entre os protestantes e o responsável pela educação dos filhos na fé, teve sua imagem valorizada. Levando-se também em consideração que ao 
protestante cabe a relação direta com Deus, sem intermediários, era preciso que este aprendesse a fazer a leitura da bíblia, alfabetizando-se.

Já em relação aos católicos, como as devoções coletivas em muito se diferenciam dos protestantes, a lgreja acabava por intervir, mesmo que suavemente, na autoridade do pai, reconhecendo, por exemplo, a legitimidade do casamento de filhos que tenham ocorrido sem a autorização do progenitor. Já no século XVII havia toda uma discussão relativa ao mandamento "honrarás pai e mãe", em que a relação dos pais com os filhos também era discutida. Neste sentido, os pais teriam deveres para com os filhos: a criação, a instrução, a repreensão e o bom exemplo. Em relação à instrução, vejamos que competia aos pais ensinar aos filhos, "eles próprios ou através de outras pessoas, os principais mistérios da fé, os mandamentos de Deus e da Igreja, o Pater e a Ave, assim como a evitar o pecado, mais ainda do que a morte" (LEBRUN, 1991, p. 91).

Lebrun destaca que, mesmo sendo os pais responsáveis pela educação dos filhos, a Igreja acabava por intervir no papel educativo, sobretudo no que se referia à instrução religiosa, não somente através de catecismos, mas através da escola (LEBRUN, [19-], p. 90-92). Nesse caso, acabamos por compreender as preocupações de Alceu Amoroso Lima (1935) em relação ao modelo de família que deveria se estruturar no Brasil do século $\mathrm{XX}$ :

\section{Pai e Chefe}

"O Brasil está tão perdido que só uma ação puramente católica poderá ainda salvá-lo", escrevia a um amigo Jackson de Figueiredo, há sete ou oito anos atrás.

O mesmo podemos repetir hoje, com crescidas razões. Só uma aliança real dos dois poderes, o espiritual e o temporal, poderá integrar em nossa vida social a ação nitidamente civilizadora da Religião. Essa aliança foi desvirtuada no Brasil pelo regalismo imperial de tal sorte que a Separação republicana foi, sob certos aspéctos, uma libertação para a Igreja.

Considerando o problema, porém, sob todas as suas faces, sabemos perfeitamente que essa Separação só póde aproveitar ás forças de dissolução nacional. A formação brasileira, ao contrário, está intimamente ligada á união constante entre as duas Autoridades, ás quais está aféta a orientação e coordenação dos dois factores fundamentais de nossa formação: o factor econômico e o factor moral. 
Ao Estado compete precipuamente a organização do trabalho.

Á Igreja compete precipuamente a organização da família.

Basta a enunciação desses postulados sociais para vermos como um e outra não pódem andar divorciados, pois o problema da família não é só um problema moral, é também um problema econômico. Do mesmo modo que o problema econômico é também um problema moral.

No plano social, portanto, o Estado e a Igreja trabalham para o mesmo fim, tanto mais quanto os dois problemas, - o do trabalho (fundamento material da sociedade) e o da família (fundamento moral da sociedade) - reúnem-se finalmente em um problema único: 0 pedagógico. E no terreno da educação encontram-se mais uma vez a Igreja e o Estado como os colaboradores da mesma obra de formação do futuro da nacionalidade [...] (LIMA, 1935, p. 27-28, grifos nossos).

É importante evidenciarmos que essa ação estratégica acabou por se encaminhar para um processo de tutela da família. Isto porque, de acordo com Antônio Manuel Hespanha (1993), muito do imaginário e dos esquemas de pensamento advindos da ordem familiar podem influenciar na configuração política da república. Em outras palavras, muito daquilo que se defendia no âmbito da casa, portanto, as relações de poder existentes no seio da família, acabavam por fundamentar o regime político das cidades. Vale destacarmos a fundamentação espiritual que então se verificava quanto a essa instituição. A união conjugal, por exemplo, era referendada a partir do episódio bíblico em que Deus criou a mulher a partir da costela do homem. O casamento seria, assim, o retorno desta ao corpo do homem. Outra característica estaria ligada à submissão dos filhos aos pais, mais uma vez numa alusão ao mandamento "honrarás pai e mãe". Assim, muitos filhos permaneciam submissos aos pais mesmo em idade adulta. Se tomarmos por base que a própria Igreja era também concebida como uma grande família, afirma Hespanha (1993, p. 968-971), levando-se em consideração, por exemplo, que era dirigida por um grande pai - seja Cristo ou o seu vigário na terra, o papa -, ou ainda a estruturação em casas de suas congregações nas quais as mulheres não tinham o mesmo poder que os religiosos homens, estes aspectos podem nos ajudar na compreensão dessa ingerência religiosa na instituição familiar.

Evitando-se a laicização do poder e das instituições políticas, visava-se recuperar funções que naquela circunstância, pelo menos no discurso político, passavam a ser entendidas como função do Estado republicano. Neste caso, como dissemos, a 
assistência e a educação primária passaram a ter importante destaque - o que acaba por nos lembrar das reformas empreendidas pela França, seja quando da Convenção Nacional (1792-1794) ou ainda quando das reformas educacionais do Consulado Napoleônico (1799-1804).

Reflexos desse momento de tensão entre o ultramontanismo e a ilustração podem ser identificados no embate entre Joaquim Nabuco e o senador Cândido Mendes. Para Joaquim Nabuco (1873a; 1873b), Cândido Mendes fazia parte do que se poderia chamar de "partido ultramontano", cujos interesses ele entendia ser prejudiciais aos interesses políticos do Estado brasileiro. Nabuco tece diversas críticas à postura dos ultramontanos. Entre elas, uma que nos parece muito interessante é relativa ao domínio católico no campo educacional, sobretudo ao se referir à Congregação das Irmãs da Caridade, que em sua visão eram as responsáveis por um grande atraso do Brasil em relação a esse setor (PINTO, 2016a, p. 156). Parece-nos que Nabuco buscava a defesa de uma Igreja nacional, uma Igreja tal qual Pombal tentara fazer no século XVIII em Portugal, à qual Nabuco tece elogios. Portanto, defende as limitações ao clericalismo existente até então no Império (NABUCO, 1873a; 1873b).

Outro reflexo deste momento pode ser identificado no fechamento de um matutino editado na década de 1880 em Minas Gerais e que fazia algumas reflexões sobre a época pombalina. Devolvido à redação pelos assinantes que não gostaram do posicionamento dos ultramontanos, o periódico nos transmitia a ideia de que o marquês de Pombal teria sido o responsável pelo descrédito que o catolicismo estaria passando no Brasil naqueles anos, uma vez que sua postura para com o jesuitismo possibilitou a circulação de uma filosofia dita "mentirosa" pela qual livres pensadores, como Voltaire, difundiram ofensas aos dogmas prescritos pelo "Redemptor da humanidade" e passaram a difundir no Brasil o positivismo, o racionalismo, o materialismo e uma série de outras invenções, conforme diz, "absurdas e subversivas".

O texto deixa claro que a mocidade, ao se atrelar a essas novidades, passava a desrespeitar e a não mais admirar, devidamente, os dogmas do cristianismo romano. De todo modo, outra mocidade, à qual se atrelava o autor do referido artigo, ainda adorava a "Luz" e estava abraçando a bandeira do Syllabus, afirmando ainda existir 
[...] denodados e valentes soldados da Luz, que não depuzeram suas armas no altar de falsos ídolos, ao brado enganador dos arautos do mal; e que, nas renhidas pugans da idéa, não cessarão de luctar um só momento, defendendo a verdade, animadas pela fé em Deus e pela esperança de uma recompensa futura (RODRIGUES, 1882, p. 3).

Neste caso, lembrar-se do marquês de Pombal seria dar crédito à maçonaria que, conforme insinua, homenageava um de seus irmãos. Percebe-se, pelo artigo, que a Igreja estava se posicionando e se organizando contra essa referida homenagem àquele que perseguiu a aristocracia portuguesa, ao grande inimigo da Companhia de Jesus, ao assassino do padre Malagrida e da família dos Távoras, além de condenar inocentes e ser capaz de todos os atos criminosos para sustentar os caprichos de sua pretensa autonomia (RODRIGUES, 1882, p. 3).

Tomemos agora o caso da antiga Escola Agrícola da Companhia União \& Indústria de Minas Gerais. Em 1884, cogitava-se a possibilidade de se fazer estabelecer nesta escola um grupo de padres salesianos. Tal ideia contava com o apoio político e financeiro da Princesa Isabel e do Conde D'Eu, que estavam à frente da Associação Protetora da Infância Desamparada, fundada logo após a Lei do Ventre Livre, de 28 de setembro de 1871. A Princesa se mostrava receptiva à ação dos salesianos na cidade do Rio de Janeiro e, por isso, tendia a influenciar para que esses padres viessem a assumir a obra da nova Escola Agrícola. Os príncipes já haviam decidido encampar a compra da referida propriedade, conforme destaca o jornal da Corte $O$ País (AZZI, 1992, p 183-184). O mesmo jornal reconhecia a necessidade de que tal Asilo fosse o quanto antes fundado, para que recebesse os desamparados da fortuna que eram tão visíveis na sociedade brasileira daquele tempo.

Cabe destacarmos que esse episódio acabou sendo direcionado para as discussões que se faziam tão pungentes no Brasil naquela época, isto é, as críticas à influência ultramontana na política brasileira. O mesmo jornal abre uma discussão em que liga os salesianos aos interesses jesuítas e ultramontanos, o que, em seu entender, poderia ser extremamente prejudicial a uma obra como aquela. A discussão segue defendendo a necessidade de um ensino agrícola livre de qualquer influência clerical, seja ela lazarista, jesuíta ou salesiana, posto que não seriam eles os melhores agrônomos que se conheciam naquela época. 
Vejamos como O País conclui suas observações em relação à obra salesiana:

Os asilos agrícolas que a Associação Protetora fundasse pelos moldes dos institutos jesuíticos dariam em resultado as antigas Reduções do Paraguai.

Não é seguramente essa a ambição dos que desejam amparar a infância desvalida.

Rompendo por uma vez com essas filiações que dizem existir entre a fundação que se pretende e a dos salesianos de Niterói; dando ao estabelecimento rural que a Associação Protetora, pelos seus estatutos, é obrigada a instalar, um regime todo civil; recolhendo nos Asilos o menino desamparado que, mais tarde, será o operário agrícola, todas as bênçãos são poucas para a humanitária associação, que vem satisfazer um dos mais instantes reclamos de nossa sociedade (AZZI, 1992, p. 184).

Provavelmente o articulista deste jornal tinha suas convicções anticlericais, liberais ou positivistas e, por isso, defendia o afastamento de uma ordem religiosa que se inseria nos planos dos reformadores ultramontanos. Ademais, além da formação agrícola voltada para o trabalho e, portanto, em consonância com o latente problema da mão de obra de meados da década de 1870, a educação oferecida em instituições como essas - que deveriam se espalhar pelo País - era também regada pela moral católica, tendo em vista as relações muito íntimas da Princesa com o catolicismo ultramontano que, para muitos, viria a conduzir suas atitudes políticas em relação à escravidão e possibilitaria a projeção do terceiro reinado no Brasil. Para a Igreja, a ascensão de Isabel ao trono possibilitaria o recrudescimento dos projetos secularizantes e laicizantes então em curso (DAIBERT JUNIOR, 2010, p. 98-99, 102, 111, 113, 115, 118, 120; PINTO, 2016b, p. 443).

Educação e assistência eram, portanto, vistos como pontos estratégicos nesse processo de mudanças institucionais. Assim, em função do desenrolar do movimento republicano, discutia-se, na passagem do século XIX ao XX, a função do Estado em relação a essas práticas, sendo que esta seria de grande relevância para a organização social e para o próprio futuro do sistema. Tornava-se importantíssima, assim, a sua concorrência para a configuração de um sistema de assistência pública que, no Brasil, ao que nos parece, era uma grande promessa do discurso político do início do século passado. 
A assistência deveria proteger a infância desamparada, a velhice desvalida, os operários inválidos e suas famílias, e auxiliar direta ou indiretamente as instituições particulares de fins humanitários ou que pudessem concorrer para a assistência direta do Estado a muitos de seus servidores. Neste contexto, era muito importante que se fundassem orfanatos, creches, gotas de leite, hospitais, estabelecimentos de educação técnica para os menores órfãos ou sem amparo e asilos para a velhice desvalida. Nesse sentido, destacava-se a atuação do governo de Minas Gerais, que estaria dando início na formação de seu sistema de assistência pública, criando em Belo Horizonte o Instituto João Pinheiro, então anexo à fazenda da Gameleira, destinado à assistência de menores que ali receberiam educação "agrozoothécnica".

O Instituto João Pinheiro pode ser pensado no conjunto das mudanças no sistema educacional que estavam ocorrendo em Minas Gerais e que tinham suas razões na fundação do próprio sistema republicano no Brasil. Assim, é preciso pensarmos que a partir de 1906, quando João Pinheiro (1860-1908) havia sido eleito presidente do Estado e cujo perfil, assim como o de Guanabara, inclinava-se para o republicanismo, o positivismo e a maçonaria (ALMEIDA FILHO, 2005, p. 51,55; GOMES, M. [19--]., p. 143), deu-se início a uma reforma educacional cujo objetivo era implantar um sistema público de ensino e a edificação e implantação da educação em grupos escolares que seriam as bases responsáveis pela irradiação do perfil republicano e liberal que se queria fundar.

O Instituto teria as características de um "self governement", referindo-se, portanto, às antigas 13 colônias inglesas na América do Norte. Deveria ser também um exemplo para que diversas outras instituições congêneres viessem a se organizar em Minas Gerais, como os patronatos agrícolas, os quais deveriam buscar educar uma geração capaz de "regenerar a terra de Minas e também o Brasil" (MINAS GERAES, 1930, p. 75). Educar essa geração, entretanto, não implicaria imprimir-lhes castigos físicos, não havendo em seu interior feitores como, àquela época, dizia-se ser possível verificar em outras instituições educacionais no Brasil (MINAS GERAES, 1930, p. 75).

João Pinheiro também se identificava com uma postura radicalmente neutra e liberal em matéria de crença espiritual. Entendia haver uma liberdade em termos de crença religiosa e, portanto, não havia uma preocupação quanto à doutrina cristã - sobretudo 
católica - em seus pavilhões. Desse modo, quisessem os internos possuir uma pequena imagem sacra ou ainda um rosário em suas camas não haveria problemas, assim como também se aos domingos desejassem ir à missa e cumprir outras tarefas que a fé lhes impunha, poderiam dirigir-se à cidade - como "verdadeiros homenzinhos" - e assim o fariam (MINAS GERAES, 1930). Para além da construção desse ideal republicano, o Instituto João Pinheiro também servia de referencial para projetos de prevenção à criminalidade.

Se a assistência pública não se apoderar da criança desamparada ela crescerá como planta daninha, cujos frutos serão a ociosidade, a embriaguez, a prostituição, o crime; na melhor hipótese, representará ela peso morto ou quantidade inexpressiva na dinâmica social; as mais das vezes, porém, constituirá o fermento da anarquia, filho da ignorância e da impotência para a luta pela vida, irá povoar os cárceres ou acabar nos hospitais (FARIA FILHO, 2001, p. 18).

Em 1909, a Revista Forense trouxe em uma de suas crônicas algumas considerações sobre essa política que se queria implantar em Minas Gerais. Nesta, identifica-se que haveria uma preocupação da sociedade em relação à formação de uma rede oficial de acolhida à criança. Logo em sua abertura fica expressa que "o socorro official á criança abandonada é obra de solidariedade humana, de convicção e de sentimento republicano, de previsão econômica e de prevenção criminal" (CRHONICA..., 1909, p. 195). Dizia também:

Ou a consideremos caridade exercida diretamente pelo Estado, ou intervenção eqüitativa delle para reparar a desigualdade na distribuição da fortuna, ou dever collectivo e christão de solidariedade humana, ou calculo utilitário de aproveitamento de factores econômicos - qualquer que seja o seu fundamento - a assistência pública á criança desherdada da proteção natural se impõe á previdência governamental. [...] A administração republicana tem de prover especialmente aos mais necessitados de auxílio público, para que a igualdade não seja um mytho e a fraternidade não se traduza numa fórmula vazia (CRHONICA..., 1909, p. 195-196).

Assim sendo, expõe Ângela de Castro Gomes (2005) que a escola João Pinheiro seria:

[...] uma escola técnica agrícola, voltada para a clientela de meninos pobres que existiam nos campos das Minas Gerais. Nela as idéias de João Pinheiro eram colocadas em prática, não apenas pela própria natureza da educação ministrada, como igualmente pelos modernos e democráticos procedimentos implantados, que previam, inclusive, a 
participação de alunos. Isso, note-se bem, antes de educadores da escola-nova defenderem e introduzirem tais princípios, o que ocorre quando do aparecimento desse movimento educacional renovador, nos anos de 1920 (p. 92-93).

Outro importante referencial de projeto educacional esteve nas mãos do deputado mineiro Fidelis Reis (1880-1962), que defendeu durante quase uma década a aprovação de um projeto de sua autoria na Câmara e no Senado Federal. Na trajetória política de Fidelis Reis podemos constatar sua visão em relação ao trabalho como solução para os males e problemas que o Brasil vivia. Além disso, evocava figuras que o auxiliaram intelectualmente nessa defesa, como Augusto Comte e João Pinheiro, que o estimulava, tendo por base a reforma educacional empreendida em seu governo sob o lema "ensinar a ler e a trabalhar".

Assim sendo, se até a década de 1920 se buscava a implantação de um aprendizado para o mercado de trabalho que moralizasse e submetesse 0 trabalhador aos interesses burgueses, sobretudo voltado para as classes mais pobres, os desafortunados e deserdados da sorte, com o projeto de Fidelis Reis se estendia essa perspectiva e obrigatoriedade para todos, fossem ricos ou pobres. No caso, todo candidato ao ensino superior deveria apresentar juntamente com os seus estudos preparatórios também o certificado de habilitação profissional (SOARES, 1995).

Embora aprovado, o projeto de Fidelis Reis não chegou a ser colocado em prática pelo governo, que argumentava a falta de recursos financeiros para tal. O início da chamada "era Vargas" também impulsionou diversas mudanças no campo educacional. De todo modo, naquela época, o projeto foi considerado "profundamente revolucionário" (REIS apud SOARES, 1995, p. 101), sendo amplamente debatido nas duas casas parlamentares, onde também teria como grandes críticos e opositores os deputados Gilberto Amado, José Maria Bello e Luís Rollemberg. Chama-nos a atenção neste episódio - além de seu uso como capaz de solucionar os problemas sociais - o recurso à assistência e à escola e a participação do Estado republicano, positivista ou liberal em sua administração.

Já o discurso do deputado Espiridião Monteiro aventou a ideia da criação do Instituto Nacional de Assistência Pública. Entretanto, como essas ideias vinham sendo tratadas pelos políticos naquele tempo, era preciso que as concepções políticas do 
deputado recém-empossado fossem acolhidas e discutidas de imediato pela Câmara, posto que, em outras situações, projetos de grande utilidade neste campo, com o tempo, perderam-se naquela instituição. De acordo com o deputado sergipano, a organização de um sistema de assistência no Brasil deveria ficar sob a tutela do Estado. Talvez, ao enfocar este requisito, o deputado sergipano estivesse com outra intenção, mas nossa fonte destaca que para um estabelecimento daquela proporção somente o poder público teria condições de sustentar.

Fontes como essas nos possibilitam entender essa disputa política que então ocorria na virada do século e que fazia o catolicismo ultramontano direcionar sua atenção para determinados setores que em sua visão eram estratégicos para a recuperação de seu apostolado. A Reforma Ultramontana e a Romanização (OLIVEIRA, 2015, p. 10) acabavam sendo uma resposta - conservadora - da Igreja à modernidade que batia à porta de seus fiéis no rastro do século XIX. Assim sendo, os pontificados de Pio IX (1846-1878) e de Leão XIII (1878-1903) acabaram se debruçando sobre esses elementos conflitantes à própria Igreja, tanto internos quanto externos.

\section{CONSIDERAÇÕES FINAIS}

Para conter essa situação desfavorável, seria necessário aprofundar ainda mais o processo reformador. Somente com a ação de um clero e ainda de congregações religiosas reformadas não seria possível atingir objetivos muito maiores, tal qual a conversão de uma classe dominante formada por bacharéis e que se responsabilizava até então pelas tentativas de reformas de cunho modernizantes no Brasil e que, como dissemos, ideologicamente se vinculava aos pensamentos políticos liberais e positivistas.

Essa situação seria detectada já nos primeiros anos do século $X X$ nos periódicos católicos que então se tornavam uma forma de "bom combate" por parte da Igreja. Esses impressos buscavam, assim, mostrar ao povo católico do Brasil as vicissitudes do novo regime e as armadilhas que este imporia ao povo. Tanto o clero regular como o secular organizaram e publicaram uma série de textos voltados a recristianizar, disciplinar e até assustar, poderíamos dizer, os que não se inseriam nos preceitos que a Igreja acreditava serem os verdadeiros, como seria o caso da assistência e da 
educação que deveriam permanecer nas mãos da Igreja e de seus intelectuais católicos.

\section{REFERÊNCIAS}

A PEDIDOS, Christianiza a República. Jornal do Commercio, Juiz de Fora, col. 2 e 3 , p. 2, 27 mar. 1904.

ALMEIDA FILHO, José Carlos de. O ensino jurídico, a elite dos bacharéis e a maçonaria no século XIX. 2005. 180 f. Dissertação (Mestrado em Direito, Estado e Cidadania) - Universidade Gama Filho, Rio de Janeiro, 2005.

AZZI, Riolando. A Igreja e o menor na história social brasileira. São Paulo: Paulinas, 1992.

AZZI, Riolando. Os jesuítas e a questão religiosa. Convergência, Rio de Janeiro, v. 11, n. 116, p. 485-510, 1978

AZZI, Riolando. Os Salesianos em Minas Gerais. São Paulo: Salesiana Dom Bosco, 1986. v. 1: O decênio inicial da obra salesiana (1895-1904).

BARATA, Alexandre Mansur. Luzes e sombras: a ação da maçonaria brasileira. Campinas: EdUNICAMP, 1999.

BEAL, Tarcísio. As raízes do regalismo brasileiro. Revista de História, Petrópolis, ano 27 , v. 54, n. 108, p. 321-340, 1976. Disponível em:

http://dx.doi.org/10.11606/issn.2316-9141.rh.1976.77808. Acesso em: 08 abr. 2021.

CARNEIRO, Orlando. Algumas notas sobre Jackson, Sergipe e o Brasil, Diário Mercantil, Juiz de Fora, col. 4 e 5, p. 2, 15 nov. 1938.

CARVALHO, José Murilo de. Os bestializados: o Rio de Janeiro e a República que não foi. São Paulo: Cia. das Letras, 1987.

CRHONICA: Assistência aos menores desvalidos. Revista Forense, Belo Horizonte, v. 11, p. 195-202, jan./jun. 1909.

DAIBERT JUNIOR, Robert. A princesa Isabel no cenário imperial: a lei Áurea e o abolicionismo católico. Revista do Instituto Histórico e Geográfico Brasileiro, Rio de Janeiro, v. 446, p. 93-125, 2010. Disponível em: https://ihgb.org.br/revista-

eletronica/artigos-446/item/108414-a-princesa-isabel-no-cenario-imperial-a-lei-aureae-o-abolicionismo-catolico.html. Acesso em: 27 abr. 2021.

FARIA FILHO, Luciano Mendes de. República, trabalho e educação: a experiência do Instituto João Pinheiro (1909-1934). Bragança Paulista: EdUSF, 2001.

FILHO, Prócoro (org.). Introdução ao protestantismo no Brasil. 2. ed. São Paulo: Loyola, 2002. p. 61-79.

GOMES, Ângela de Castro. Memória, política e tradição familiar. In: GOMES, Ângela de Castro (org.). Minas e os fundamentos do Brasil moderno. Belo Horizonte: UFMG, 2005. p. 79-108. 
GOMES, Manoel. A maçonaria na história do Brasil. Rio de Janeiro: Aurora, [19--].

HAUCK, João Fagundes et al. História da Igreja no Brasil. 3. ed. Petrópolis: Vozes e Edições Paulinas, 1992. v. 2: Segunda Época-Século XIX.

HESPANHA, António Manuel. Carne de uma só carne: para uma compreensão dos fundamentos histórico-antropológicos da família na época moderna. Análise social, Lisboa, v. 28, n. 123-124, p. 951-973, 1993. Disponível em:

http://analisesocial.ics.ul.pt/documentos/1223293699K2wUQ7iq8Pw47EV0.pdf.

Acesso em: 27 abr. 2021.

http://repositorio.unicamp.br/handle/REPOSIP/281127. Acesso em: 27 abr. 2021.

LEBRUN, François. As reformas: devoções comunitárias e piedade pessoal. In: ARIÈS, Phillippe; ROGER, Chartier (org.). História da vida privada. São Paulo: Cia. das Letras, 1991. v. 3: da Renascença ao século das luzes.

LEBRUN, François. O sacerdote, o príncipe e a família. In: LEBRUN, François. História da Família. Lisboa: Terramar, [19--].

LICEU de artes e offícios de Uberaba. Lançamento da pedra fundamental. Discurso do Deputado Dr. Fidelis Reis, [1926?].

LIMA, Alceu Amoroso. Pai e Chefe (1930). In: LIMA, Alceu Amoroso. Pela Ação Católica. Rio de Janeiro: Biblioteca Anchieta, 1935. p. 27-46.

MAINWARING, Scott. Igreja Católica e política no Brasil (1916-1985). São Paulo: Brasiliense, 2004.

MENDONÇA, Antônio Gouvêa. A "questão religiosa": conflito Igreja versus Estado e expansão do protestantismo. In: MENDONÇA, Antônio Gouvêa; VELASQUES

MENDONÇA, Antônio Gouvêa; VELASQUES FILHO, Prócoro. Introdução ao protestantismo no Brasil. 2. ed. São Paulo: Loyola, 2002.

MICELI, Sergio. A elite eclesiástica brasileira. Rio de Janeiro: Bertrand Brasil, 1988.

MINAS GERAES. A assistência à infância desvalida em Minas Gerais. Belo Horizonte: Imprensa Oficial do Estado de Minas Gerais, 1930.

NABUCO, Joaquim. A invasão ultramontana: discurso pronunciado no Grande Oriente do Brasil, no dia 20 de maio de 1873. Rio de Janeiro: Typographia FrancoAmericana, 1873b.

NABUCO, Joaquim. O partido ultramontano: suas invasões, seus órgãos e seu futuro. Artigos publicados. Rio de Janeiro: Typografia da Reforma, 1873a.

OLIVEIRA, Gustavo de Souza. Aspectos do ultramontanismo oitocentista: Antônio Ferreira Viçoso e a Congregação da Missão em Portugal e no Brasil (1811-1875). 2015. Tese (Doutorado em História) - Instituto de Filosofia e Ciências Humanas, Universidade Estadual de Campinas, Campinas, 2015. Disponível em:

PINTO, Jefferson de Almeida. O processo de anistia aos bispos da "Questão Religiosa": Historiografia, Direito Constitucional e Diplomacia. Passagens, Niterói , v. 8, n. 3, p. 426-451, set./dez. 2016b. Disponível em: 
https://periodicos.uff.br/revistapassagens/article/view/45924. Acesso em: 27 abr. 2021.

PINTO, Jefferson de Almeida. Os lazaristas e a política imperial - a escola, a assistência e a família. Topoi [online], Rio de Janeiro, vol. 17, n. 32, p.153-175, jan./jun. 2016a. Disponível em: http://dx.doi.org/10.1590/2237-101X0173209. Acesso em: 27 abr. 2021.

RELIGIÃO e política, Diário Mercantil, Juiz de Fora, col. 1, p. 1, 5 de mar. 1932.

RODRIGUES, Jorge. Marquês de Pombal, Gazeta de Juiz de Fora, Juiz de Fora, col. 1, p. 3, 11 maio 1882.

ROMANO, Roberto. Brasil: Igreja contra Estado. São Paulo: Kairós, 1979.

SANTIROCCHI, Ítalo Domingos. Questão de consciência: os ultramontanos no Brasil e o regalismo do Segundo Reinado (1840-1889). Belo Horizonte: Fino Trato, 2015.

SERBIN, Kenneth P. Padres, celibato e conflito social: uma história da Igreja Católica no Brasil. São Paulo: Cia. das Letras, 2008. p. 78-79.

SOARES, Manoel de Jesus Araújo. Uma nova ética do trabalho nos anos $20-$ projeto Fidelis Reis. Relatos de pesquisa, [S. I.], v. 4, n. 33, p. 98-105, 3 mar. 1995. Disponível em:

http://relatos.inep.gov.br/ojs3/index.php/relatos/article/view/4070/3616. Acesso em: 08 abr. 2021.

VIEIRA, David Gueiros. O protestantismo, a maçonaria e a questão religiosa no Brasil. 2. ed. Brasília: EdUnB, 2006. 